\title{
DOTAZNÍK INTERPERSONÁLNÍCH HODNOT (SIPO) Recenze metody
}

AUTOŘI RECENZE: MARTIN ŠTÝBER ${ }^{1}$

\begin{tabular}{|l|l|}
\hline \multicolumn{1}{|c|}{ datum vzniku recenze: } & 5.1.2021 \\
\hline 1.1 název nástroje: & Dotazník interpersonálních hodnot \\
\hline \multicolumn{1}{|c|}{ zkrácený název: } & Dotazník SIPO \\
\hline 1.2 původní název: & Survey of interpersonal values (SIV) \\
\hline 1.4 autoři původního testu: & L. V. Gordon \\
\hline 1.3 autoři lokální adaptace: & O. Mikšík \\
\hline 1.7 lokální distributor: & Psychodiagnostika s.r.o., Brno \\
\hline $1.9 .1 / 1.9 .2$ datum vydání: & 2004 \\
\hline
\end{tabular}

\section{Obecný popis}

Dotazník SIPO je osobnostní dotazník určený k měření interpersonálních hodnot, které mohou hrát roli ve vztazích s druhými lidmi. Výsledkem testu jsou hodnoty seřazené hierarchicky, ze kterých lze vidět, které hodnoty mají dominující postavení. Dle vydavatele je test určen pro populaci od 13 let a horní hranice není stanovena. Jedná se o krátký test trvající zhruba 15 minut.

Dotazník má dohromady šest škál. Tři z nich se zaměřují na to, co člověk očekává od druhých: očekávání porozumění, očekávání uznání a očekávání nezávislosti. Zbývající tři škály se zaměřují na to, jak se člověk projevuje k druhým lidem: projevování dominance, projevování konformity a projevování altruismu. Dotazník je možné využít ve dvou variantách. Je možné jej vyplnit ručně, anebo je možnost využít počítačový program. Dle autora může mít tento dotazník uplatnění pro vytváření akceschopných týmů s náročným posláním. Pořizovací cena pracovního kompletu je 1937 Kč bez DPH. Cena za SIPO software DiarosWin je 3890 Kč bez DPH.

Dotazník SIPO původně vychází ze zahraniční metody SIV (Survey of interpersonal values), která vznikla v roce 1960. Autorem české adaptace SIPO je Oldřich Mikšík a test vyšel v roce 2004. Vydavatelem testu je Psychodiagnostika, a.s. Dotazníku SIPO je

\footnotetext{
${ }^{1}$ Katedra psychologie, Fakulta sociálních studií MU, Joštova 10, 60200 Brno
} 
v Mikšíkových knihách věnováno poměrně málo prostoru oproti jeho dalším nástrojům jako je SPARO, SUPSO, DUSIN a další. Svoboda kupř́íkladu dotazník SIPO ani nezahrnuje ve svém přehledu Mikšíkových dotazníků (Svoboda a kol., 2013). Z tohoto důvodu vycházím $\mathrm{v}$ této recenzi primárně z materiálů obsažených při zakoupení testu, z pár Mikšíkových knih (Mikšík 1999, 2001) a ze zahraniční recenze věnující se původní verzi metody.

\section{Vývoj metody}

Není zcela jasné, jakým způsobem byl dotazník zkonstruován. V manuálu není uvedeno, že dotazník SIPO vychází z nějaké zahraniční metody, avšak v jedné ze svých knih Mikšík uvádí, že dotazník SIPO vychází z Gordonovy koncepce dotazníku SIV (Mikšík, 2001). V manuálu však ale neuvádí nic k postupu adaptace metody.

Gordon pomocí faktorové analýzy vymezil 6 interpersonálních hodnot, které ovlivňují vztah člověka $\mathrm{k}$ lidem. Tyto hodnoty jsou téměř identické $\mathrm{s}$ hodnotami měřenými dotazníkem SIPO. Některé se lehce liší názvem: podpora, konformita, uznání, nezávislost, benevolence a vůdcovství. Gordon teoreticky navazuje na Sprangerovu typologii hodnotových orientací. Spranger vytvořil typologií, která dělí lidi do 6 základních typů: osobnost teoreticky orientovaná, ekonomicky orientovaná, sociálně orientovaná, esteticky orientovaná, politicky orientovaná a nábožensky orientovaná. Podle Gordona se každý tento typ vyznačuje vysokou mírou určitých interpersonálních hodnot. Např́klad osobnost teoreticky orientovaná se vyznačuje vysokou tendencí $\mathrm{k}$ nezávislosti a vůdcovství (Mikšík 1999, 2001).

Struktura položek Mikšíkova dotazníku SIPO se liší od původního dotazníku SIV. Dotazník SIV obsahuje 30 položek, v nichž má respondent na výběr ze tří výroků. Z těchto tř́i výroků si respondent zvolí, který výrok je pro něj nejdůležitější a který je pro něj nejméně důležitý. Oproti tomu dotazník SIPO má 90 položek, ve kterých si respondent volí ze dvou výroků, který je pro ně důležitější. Není jasné, proč Mikšík takto změnil strukturu položek. Rovněž Mikšík rozdělil původních 6 Gordonových interpersonálních hodnot do dvou kategorií. Na trři, které člověk vyžaduje od okolí a na třii, které projevuje do okolí. Díky těmto změnám se nedá př́liš usuzovat na přejímání psychometrických důkazů původní metody na metodu českou.

\section{Technické parametry}

Text manuálu je psaný poměrně složitým jazykem, který činí porozumění náročné pro čtenáře. Je občas obtížné pochopit, jak danou věc autor myslel. Pozitivní stránkou je snadná administrace testu. Zároveň vyhodnocení testu pomocí šablon je velmi jednoduché a převedení hrubého skóru na z-skór je dobře popsáno. Tam však pokyny končí a interpretace výsledků spolu se zpětnou vazbou testované osobě je závislá na odbornosti a úsudku uživatele testu. 
Znepokojivým objevem je to, že minimálně jedna z položek testu sytí špatnou škálu. Položka 44a zní: „Respektovat názory druhých a řídit se jimi.“ Tato položka má podle vyhodnocovací šablony sytit škálu dominance, ale evidentně je v rozporu s definicí dominance $\mathrm{v}$ manuálu testu (nejspíše byla zamýšlena k sycení škály konformity). U žádných jiných položek nebyl nalezen takto evidentní rozpor, ale bez kvalitní analýzy je nemožné určit, zda to je jediná problematická položka. Je mrzuté, že během vývoje testu neproběhla faktorová nebo položková analýza, které by mohly takové věci odhalit.

\section{Validita}

Autor české metody se $\mathrm{k}$ validitě nikde $\mathrm{v}$ manuálu explicitně nevyjadřuje. Mikšík se v psychometrické části příručky věnuje především korelacím mezi dotazníkem SIPO a dalšími nástroji (převážně se zaměřuje na korelace s dalšími Mikšíkovými testy). Většina těchto výsledků je pro posouzení kvality metody nepodstatná a autor nevysvětluje, z jakého důvodu jim věnuje takový prostor. Nicméně se dá z některých výsledků alespoň zčásti usuzovat na konstruktovou validitu. Korelační analýza dotazníku SPARO s dotazníkem SIPO byla provedena na vzorku 4732 mužů a 2531 žen. Dotazník SPARO je obsáhlou baterií, která měří strukturu a dynamiku bazální psychické autoregulace a integrovanosti osobnosti (Mikšík, 2004). Výsledky ukazují: korelaci mezi konformitou (SPARO) a projevováním konformity (SIPO) $r=0,39$ pro muže a $r=0,41$ pro ženy; korelaci mezi hladinou benevolence a tolerance (SPARO) a altruismem (SIPO) $r=0,20$ pro muže a $\mathrm{r}=0,23$ pro ženy; korelaci mezi tendencí $\mathrm{k}$ nezávislosti (SPARO) a očekáváním nezávislosti (SIPO) $r=0,37$ pro muže a $r=0,36$ pro ženy. Autor také zkoumal na 307 mužích vztah dotazníku SIPO s dotazníkem interpersonální orientace FIRO-B. Zde se dá pro účely konstruktové validity zaměřit na: korelaci mezi mírou kontrolování druhých (FIRO-B) a projevováním dominance (SIPO) $\mathrm{r}=0,42$; korelaci mezi potřebou být milován (FIRO-B) a očekáváním uznání (SIPO) r = -0,10. Mikšík nikde nereflektuje to, že některé tyto hodnoty jsou neuspokojivě nízké.

Původní verze metody vykazuje dobrou úroveň prediktivní i konstruktové validity (Kaczmarek \& Packer, 1997). Co se týče konstruktové validity můžeme například zmínit studii, kdy ve vzorku 71 vědců vůdcovství (SIV) korelovalo s mírou kontrolování druhých (FIRO-B) $r=0,60$ (Gordon, cit. podle Kaczmarek \& Packer, 1997). Co se týče prediktivní validity, ve studii sledující 706 vojenských kadetů bylo zjištěno, že ti, kteří skončili výcvik z vlastní vůle, častěji skórovali výše $\mathrm{v}$ dimenzi nezávislosti a nízko v dimenzi konformity (Tupes, cit. podle Kaczmarek \& Packer, 1997). Dobrá validita původní metody však nemusí znamenat dobrou validitu české metody.

\section{Reliabilita}

Autor původní metody ověřoval test-retest reliabilitu na několika vzorcích. Vysokoškolští studenti $(n=79)$ byli znovu otestováni po desíti dnech a jejich koeficienty byly mezi $r=$ 0,78 až $\mathrm{r}=0,89$. Koeficienty reliability pro dobrovolníky z mírových sborů $(\mathrm{n}=58)$ retestovaných po 12 týdnech byly mezi $r=0,55$ až $r=0,79$. Koeficienty pro další 
retestované vzorky ukazovaly podobné hodnoty. Vnitřní konzistence škál se pro vysokoškolské studenty $(\mathrm{n}=186)$ pohybovala mezi KR20 $=0,71$ až KR20 $=0,86$. Podobně pro studenty střední školy $(n=144)$ byla vnitřní konzistence pro jednotlivé škály mezi KR20 = 0,75 až KR20 = 0,86 (Gordon, cit. podle Kaczmarek \& Packer, 1997). Koeficienty původní metody ukazují většinou dostatečně dobrou úroveň reliability.

Víceméně uspokojivá reliabilita originální verze však neznamená podobnou reliabilitu české verze, zvláště protože originální metoda používá jinou strukturu položek v dotazníku. Autor české metody vůbec koeficienty reliability neuvádí. Rovněž manuál neposkytuje žádné informace $\mathrm{k}$ intervalům spolehlivosti a standardní chybě měření.

\section{Normy}

V původní metodě použil autor pro konstrukci norem 5 vzorků americké populace napříč věkem a vzděláním dohromady čítající 13856 respondentů. Menšinové skupiny byly zastoupeny napříč těmito vzorky, což je dle autora důkazem reprezentativnosti amerického vzorku (Gordon, cit. podle Kaczmarek \& Packer, 1997). Hrubé skóry se v dotazníku SIV převádí na percentily.

Autor české metody zjistil na vzorku 752 mužů od 18 do 56 let, že jednotlivé škály jsou nezávislé na věku, tudíž v ručním vyhodnocování se s věkovými normami nepracuje. Ačkoliv byla věková nezávislost zkoumána pouze u lidí starších 18 let, vydavatel testu uvádí, že metoda je vhodná pro respondenty od 13 let. Při ručním vyhodnocení pracuje člověk bud' s normami pro muže $(n=5090)$, nebo pro ženy $(n=2730)$. Velikost obou skupin je velmi uspokojivá a toto rozhodně oceňuji. V př́ručce však nejsou uvedeny žádné informace o tom, jakým způsobem byl tento soubor sesbírán, ani žádné další charakteristiky zkoumaného vzorku (včetně vzdělání, věku nebo stáří norem). Uživatel testu nemá mnoho informací, aby posoudil, s jakou populací je skóre respondenta porovnáváno.

Oproti původní metodě se v dotazníku SIPO nepřevádí hrubé skóry na percentily ale na zskóry. Distributor nabízí koupi počítačového programu DiarosWin, který umožňuje uživateli testu vyhodnocovat skóry nejen z hlediska obecných populačních norem, ale i z hlediska vybraných populací obsažených v databázi. Zejména pro výzkumné účely je v programu také možnost porovnávat mezi sebou předem definované skupiny pomocí ttestů. Nástroj DiarosWin zároveň poskytuje grafické vyjádření z-skórů.

\section{Závěr}

Dotazník SIPO má dle mého názoru několik problémových částí, které nemusí být při koupi testu zřejmé. Manuál $\mathrm{k}$ testu postrádá mnoho základních informací. Autor $\mathrm{v}$ manuálu neposkytuje žádné údaje o vývoji metody ani to, že metoda je adaptací už existující zahraniční metody. Zároveň zde autor neposkytuje žádné odkazy na další relevantní výzkumy. Nenávazností na širší psychologické poznání a specifičností použitého jazyka působí metoda velmi vytrženým dojmem, jako by autor vycházel 
z nějaké úplně jiné psychologie. Celkově chybí bližšś přiblížení teoretických východisek, ze kterých metoda vychází. V manuálu také chybí postup tvorby položek a položková analýza. Tento nedostatek se odráží na kvalitě položek, z nichž některé se zdají být problematické už jen při jejich pročtení.

Základním nedostatkem je také propracovaný psychometrický manuál, který by se blíže zabýval reliabilitou, validitou a normami. V psychometrické části manuálu se autor převážně věnuje korelacím mezi nástrojem SIPO a dalšími nástroji. Většina těchto výsledků je však poměrně nepodstatná k posouzení kvality metody. Výběr metod a přehledy korelací působí nejasným dojmem, protože autor neuvádí, za jakým účelem jsou tyto výsledky prezentovány.

\section{Shrnutí a doporučení}

Dotazník interpersonálních hodnot SIPO je snadným nástrojem, jehož administrace je velmi krátká a vyhodnocování pomocí šablon je jednoduché. Na druhou stranu manuál k dotazníku SIPO neposkytuje skoro žádné údaje ke kvalitnímu zhodnocení jeho psychometrických vlastností. Hlavním nedostatkem jsou chybějící důkazy validity a reliability. Dalším problémem jsou také nedostatečné informace k používaným normám, které mohou být pro účel testování neadekvátní nebo zastaralé. Pokud se psychometrickými vlastnostmi dotazníku SIPO Mikšík někdy zabýval, rozhodně nejsou tato data snadno dostupná běžnému uživateli testu. Vzhledem ke všem těmto nedostatkům nelze doporučit dotazník SIPO k praktickému používání. Za současného stavu, lze dotazník SIPO použít maximálně $\mathrm{k}$ výzkumným účelům, přičemž výzkumník by měl být obezřetný ke všem slabým místům metody.

\section{Zdroje}

Gordon, L. V. (1960). Survey of Interpersonal Values. Chicago: Science Research Associates.

Kaczmarek, A. \& Packer, J. (1997). Determination of a job-related test battery for the psychological screening of police applicants. Payneham: National Police Research Unit.

Mikšík, O. (1999). Psychologické teorie osobnosti. Praha: Karolinum.

Mikšík, O. (2001). Psychologická charakteristika osobnosti. Praha: Karolinum.

Mikšík, O. (2004). Dotazník SIPO. Brno: Psychodiagnostika.

Svoboda, M., Humpolíček, P., \& Šnorek, V. (2013). Psychodiagnostika dospělých. Portál. 


\author{
EFPA \\ STANDING COMMITTEE ON \\ TESTS AND TESTING (SCTT)
}

Příloha ke Zprávě předsedy, 2005

MODEL RECENZE PODLE EFPA PRO POPIS

A HODNOCENÍ PSYCHOLOGICKÝCH TESTŮ

FORMULÁŘ RECENZE TESTU A POZNÁMKY PRO RECENZENTY

Verze 3.42

Lokální úprava pro časopis Testforum

ISSN 1805-9147 


\section{MODEL RECENZE PODLE EFPA PRO POPIS \\ A HODNOCENÍ PSYCHOLOGICKÝCH TESTŮ \\ FORMULÁŘ RECENZE TESTU A POZNÁMKY PRO \\ RECENZENTY ${ }^{1}$}

Toto je lokální úprava dokumentu pro účely publikace v časopise Testfórum.

Originální český překlad je k dispozici na stránkách EFPA

(www.efpa.eu/download/505cd9db4144ecb16174087909c9cd6d).

Původní verzi sestavil a uspořádal Dave Bartram

Doplnili a revidovali Patricia Lindley, Dave Bartram a Natalie Kennedy v dubnu $2004^{2}$

Současná verze 3.42: květen 2005

Český překlad: Tomáš Urbánek

Od uživatelů tohoto dokumentu a jeho obsahu žádá EFPA, aby uznali tento zdroj prostřednictvím následujícího textu:

"Kritéria pro recenzi testu podle EFPA do značné míry vychází z formy a obsahu kritérií pro recenze testů Britské psychologické společnosti (BPS) a kritérií vytvořených Komisí pro testové záležitosti (COTAN) Holandské asociace psychologů (NIP). Dave Bartram a Patricia Lindley původně vyvinuli kritéria BPS a recenzní procedury pro UK Employment Service a později rozšírili jejich používání pro celou BPS. Arne Evers připravil k vydání nizozemský system posuzování kvality testů.

EFPA je vděčná BPS a NIP za svolení použít jejich kritéria jako základ pro vytvoření evropského modelu. EFPA je také vděčná Davu Bartramovi, Arnu Eversovi a Patricii Lindley za jejich přispění $k$ vývoji tohoto modelu. Veškerá intelektuální vlastnická práva původních kritérií podle BPS a NIP jsou nadále uznávána a náleží těmto orgánům."

\footnotetext{
1 Tento dokument byl vytvořen z několika zdrojů, včetně Hodnotícího formuláře pro recenzi testu používaného v BPS (NPAL a Řídící komise pro testové standardy při BPS - Steering Committee on Test Standards), Španělského dotazníku pro hodnocení psychometrických testů (Španělská psychologická asociace) a Systému pro posuzování kvality testu (Komise pro testování Holandské asociace psychologů). Některé části byly adaptovány se svolením z dokumentu: BPS Books Reviews of Level B Assessment Instruments for use in Occupational Assessment, Notes for Reviewers: Version 3.1. December 1998: Copyright (C) NPAL, 1989, 1993, 1998.

2 Současná verze je spojením dvou oddělených dokumentů (Formuláře recenze a Poznámek pro recenzenty). Obsah byl navíc uspořádán a doplněn na základě jeho používání recenzenty online testů v BPS.
} 


\section{Část 1:}

Popis nástroje: Obecné informace a klasifikace

\begin{tabular}{|c|c|c|}
\hline & Recenzent 1: & Martin Štýber \\
\hline & Recenzent 2: & \\
\hline & Konzultující editor: & Mgr. Jaroslav Gottfried \\
\hline & Vedoucí editor: & Mgr. Hynek Cígler, Ph.D. \\
\hline & $\begin{array}{l}\text { Vedoucí editor aktualizace: } \\
\text { (pouze v př́padě aktualizací) }\end{array}$ & \\
\hline & $\begin{array}{l}\text { Editor aktualizace: } \\
\text { (pouze v prŕpadě aktualizací) }\end{array}$ & \\
\hline & Datum vzniku této recenze: & 5. 1.2021 \\
\hline \multirow[t]{2}{*}{1.1} & Název nástroje (lokální verze): & Dotazník interpersonálních hodnot \\
\hline & Zkrácená verze názvu testu: & Dotazník SIPO \\
\hline 1.2 & $\begin{array}{l}\text { Původní název testu (pokud je lokální } \\
\text { verze adaptací): }\end{array}$ & Survey of interpersonal values (SIV) \\
\hline 1.4 & Autoři původního testu: & L. V. Gordon \\
\hline 1.3 & Autoři lokální adaptace: & O. Mikšík \\
\hline 1.7 & Lokální distributor/vydavatel testu: & Psychodiagnostika s.r.o., Brno \\
\hline 1.8 & $\begin{array}{l}\text { Vydavatel původní verze testu (pokud je } \\
\text { jiný než současný distributor/vydavatel): }\end{array}$ & \\
\hline 1.9 .1 & Datum vydání současné revize/vydání: & 2004 \\
\hline 1.9 .2 & $\begin{array}{l}\text { Datum vydání adaptace pro lokální } \\
\text { užívání: }\end{array}$ & 1994 \\
\hline 1.9 .3 & Datum vydání původního testu: & 1960 \\
\hline
\end{tabular}




\section{Obecný popis nástroje}

Dotazník SIPO je osobnostní dotazník určený k měření interpersonálních hodnot, které mohou hrát roli ve vztazích s druhými lidmi. Výsledkem testu jsou hodnoty seřazené hierarchicky, ze kterých lze vidět, které hodnoty mají dominující postavení.

Dotazník má dohromady šest škál. Tři z nich se zaměřují na to, co člověk očekává od druhých: očekávání porozumění, očekávání uznání a očekávání nezávislosti. Zbývající tři škály se zaměřují na to, jak se člověk projevuje k druhým lidem: projevování dominance, projevování konformity a projevování altruismu. Dle autora může mít tento dotazník uplatnění pro vytváření akceschopných týmů s náročným posláním.

Dle vydavatele je test určen pro populaci od 13 let a horní hranice není stanovena. Jedná se o krátký test trvající zhruba 15 minut.

Dotazník SIPO původně vychází ze zahraniční metody SIV (Survey of interpersonal values), která vznikla v roce 1960. Autorem české adaptace SIPO je Oldřich Mikšík a test vyšel v roce 2004 (původně 1994). Vydavatelem testu je Psychodiagnostika, a.s.

\section{Část 2:}

Klasifikace

\begin{tabular}{|c|c|c|}
\hline 1.10 .1 & Obsahová doména & $\begin{array}{ll} & \text { Školní schopnosti } \\
\square & \text { Všeobecné schopnosti } \\
\square & \text { Verbální schopnosti } \\
\square & \text { Numerické schopnosti } \\
\square & \text { Prostorové schopnosti } \\
\square & \text { Neverbální schopnosti } \\
\square & \text { Rychlost vnímání } \\
\square & \text { Pamět' } \\
\square & \text { Manuální zručnost } \\
\square & \text { Osobnost - Rys } \\
\square & \text { Osobnost - Typ } \\
\square & \text { Osobnost - Stav } \\
\square & \text { Kognitivní styly } \\
\square & \text { Motivace } \\
\square & \text { Hodnoty } \\
\square & \text { Zájmy } \\
\square & \text { Přesvědčení } \\
\square & \text { Poruchy a patologie } \\
\square & \text { Skupinové procesy } \\
\square & \text { Rodina } \\
\square & \text { Organizace, její fungování, agregovaná } \\
\text { měření, klima atd. } \\
\square \text { Školní nebo výchovné funkce } \\
\square \text { Jiné: }\end{array}$ \\
\hline
\end{tabular}




\begin{tabular}{|c|c|c|}
\hline 1.10 .2 & $\begin{array}{l}\text { Zamýšlená(é) nebo hlavní oblast(i) } \\
\text { použití. }\end{array}$ & $\begin{array}{ll}\square & \text { Klinická psychologie } \\
\square & \text { Neuropsychologie } \\
\square & \text { Forenzní psychologie } \\
\square & \text { Psychologie výchovy a vzdělávání } \\
\square & \text { Psychologie práce a personalistika } \\
\square & \text { Poradenství, doporučení, vedení a volba } \\
& \text { povolání } \\
\square & \text { Psychologie zdraví, životní styl a životní } \\
& \text { spokojenost } \\
\square & \text { Sporty a volný čas } \\
\square & \text { Jiné: }\end{array}$ \\
\hline 1.10 .3 & $\begin{array}{l}\text { Zamýšlený způsob použití } \\
\text { (podmínky, za jakých byl nástroj } \\
\text { standardizován a validizován) }\end{array}$ & $\begin{array}{l}\text { Nesupervidovaná administrace bez } \\
\text { kontroly nad identitou respondenta a bez } \\
\text { úplné kontroly nad podmínkami } \\
\text { administrace (např. volně přístupný test } \\
\text { na internetu, test dostupný ke koupi v } \\
\text { knihkupectví). } \\
\text { Kontrolovaný nesupervidovanou } \\
\text { administrcí. Kontrola nad podmínkami } \\
\text { (čas atd.) a určitá kontrola nad identitou } \\
\text { uživatele testu (např. testy } \\
\text { administrované přes internet, ale pouze } \\
\text { známým osobám - př́ístup omezený } \\
\text { heslem). } \\
\text { Supervidovaná a kontrolovaná } \\
\text { administrace. Administrace testu pod } \\
\text { kontrolou kvalifikovaného adminitrátora } \\
\text { nebo dohlížitele. } \\
\text { Řízená administrace. Administrace testu } \\
\text { prováděná pouze přes určená testovací } \\
\text { centra (např. programy hodnocení licencí } \\
\text { a certifikace). }\end{array}$ \\
\hline 1.10 .4 & $\begin{array}{l}\text { Popis populací, pro které je test } \\
\text { určen: }\end{array}$ & Populace od 13 let \\
\hline 1.10 .5 & $\begin{array}{l}\text { Počet škál a krátký popis } \\
\text { proměnné nebo proměnných } \\
\text { měřených nástrojem }\end{array}$ & $\begin{array}{ll}\text { Škál je } 6 \\
\text { 1. } & \text { Očekávání porozumění } \\
\text { 2. } & \text { Očekávání uznání } \\
\text { 3. } & \text { Očekávání nezávislosti } \\
\text { 4. } & \text { Projevování dominance } \\
\text { 5. } & \text { Projevování konformity } \\
\text { 6. } & \text { Projevování altruismu }\end{array}$ \\
\hline
\end{tabular}




\begin{tabular}{|c|c|c|}
\hline 1.11 & Formát položek & $\begin{array}{ll}\square & \text { Otevřený } \\
\square & \text { Mnohonósobná volba, alternativy na } \\
& \text { stejné škále } \\
\square & \text { Bipolární adjektiva } \\
\square & \text { Likertovy ratingy (škály) } \\
\otimes & \text { Nucená volba, alternativy na smíšených } \\
\text { škálách (ipsativní) - vysvětlení viz } \\
\text { Poznámky } \\
\square \text { Mnohonásobná volba, alternativy na } \\
\text { smíšných škálách (ipsativní) - } \\
\text { vysvětlení viz Poznámky } \\
\square \text { Sady párů adjektiv (sémantický } \\
\text { diferenciál), smíšené škály (ipsativní) } \\
\square \quad \text { Jiné: }\end{array}$ \\
\hline 1.12 & Počet položek testu: & Celkový počet položek testu je 90 \\
\hline 1.13 & Způsob(y) administrace: & $\begin{array}{ll} & \text { Interaktivní individuální administrace } \\
\otimes & \text { Supervidovaná skupinová administrace } \\
\square & \text { Počítačová lokálně nainstalovaná } \\
\text { aplikace - pod supervizí/dohledem } \\
\square \\
\text { Počítačová aplikace na webu - pod } \\
\text { supervizí/dohledem } \\
\square \\
\text { Počítačová lokálně nainstalovaná } \\
\text { aplikace - bez supervise/testování sebe } \\
\square \\
\text { Počítačová aplikace na webu - bez } \\
\text { supervize/testování sebe } \\
\square \text { Jiné: }\end{array}$ \\
\hline 1.14 & Způsob odpovídání: & $\begin{array}{ll}\square & \text { Ústní rozhovor } \\
\bigotimes & \text { Papír a tužka } \\
\square & \text { Manuální operace } \\
\square & \text { Na počítači } \\
\square & \text { Jiné: }\end{array}$ \\
\hline
\end{tabular}




\begin{tabular}{|c|c|c|c|}
\hline 1.15 & 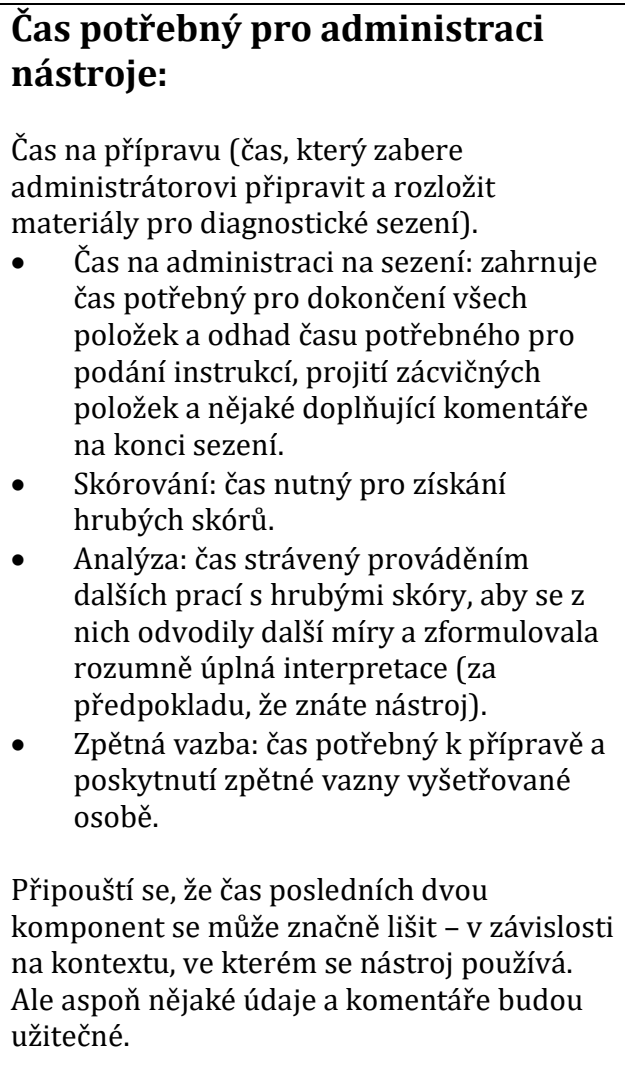 & $\begin{array}{l}\text { Příprava: } \\
\text { Administrace: } \\
\text { Skórování: } \\
\text { Analýza: } \\
\text { Zpětná vazba: } \\
\text { Čas pro přípra } \\
\text { zpětnou vazbu }\end{array}$ & $\begin{array}{l}\text { - } \\
15 \text { minut, ale vyplňování } \\
\text { není časově omezeno } \\
\text { - } \\
\text { - } \\
\text { - } \\
\text { u, skórování, analýzu a } \\
\text { nejsou uvedeny. }\end{array}$ \\
\hline 1.16 & $\begin{array}{l}\text { Jsou k dispozici různé formy } \\
\text { nástroje? }\end{array}$ & \multicolumn{2}{|c|}{$\begin{array}{l}\text { Dotazník SIPO je možné vyplnit ručně } \\
\text { tužka-papír, ale i počítačově. }\end{array}$} \\
\hline
\end{tabular}

\section{Č́ást 3:}

\section{Měření a skórování}

\begin{tabular}{|c|c|c|}
\hline 1.17 & Procedura skórování testu: & 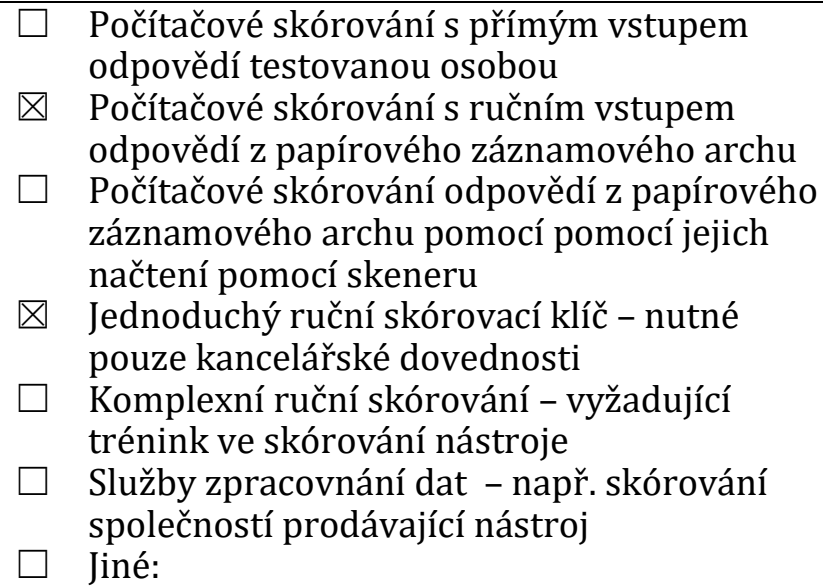 \\
\hline 1.18 & Skóry: & Součtové skóry jsou převedeny na z-skóry. \\
\hline 1.19 & $\begin{array}{l}\text { Transformace skóru na standardní } \\
\text { skóry: }\end{array}$ & $\begin{array}{ll} & \text { Normalizovaná - skóry se získají použitím } \\
\text { normalizační tabulky } \\
\square \\
\text { Nenormalizovaná - skóry se získají lineární } \\
\text { transformací }\end{array}$ \\
\hline
\end{tabular}




\begin{tabular}{|c|c|c|}
\hline 1.20 & Použité škály & 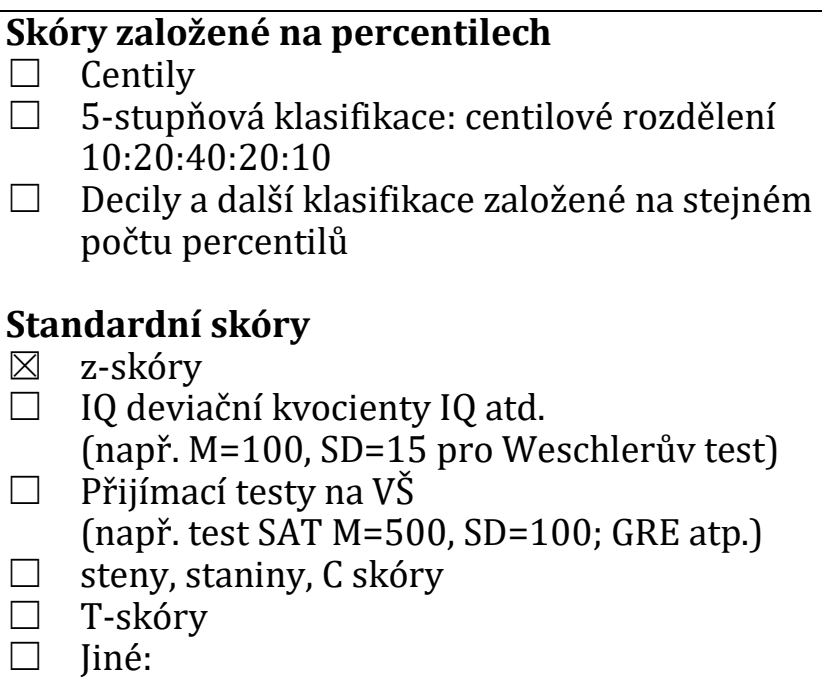 \\
\hline
\end{tabular}

Č́ást 4:

Počítačově generované zprávy

Toto je čistě popisné. Hodnocení zpráv bude součástí části recenze nazvané Hodnocení.

\begin{tabular}{|l|l|ll|}
\hline 1.21 & $\begin{array}{l}\text { Jsou počítačově generované zprávy } \mathbf{k} \\
\text { dispozici s nástrojem? }\end{array}$ & $\square \quad$ Ano \\
& $\bigotimes \quad \mathrm{Ne}$ \\
\hline
\end{tabular}

\section{Č́st 5:}

\section{Nabídka, podmínky a náklady}

Tato část definuje, co vydavatel poskytne, komu, za jakých podmínek a za jaké ceny. Definuje podmínky kladené dodavatelem a týkající se toho, kdo smí a kdo nesmí získat materiál nástroje. Pokud jedna z možností neodpovídá podmínkám nabídky, doplňte popis relevantních podmínek.

\begin{tabular}{|c|c|c|}
\hline 1.23 & $\begin{array}{l}\text { Dokumentace poskytovaná } \\
\text { distributorem jako součást } \\
\text { testového balíku }\end{array}$ & 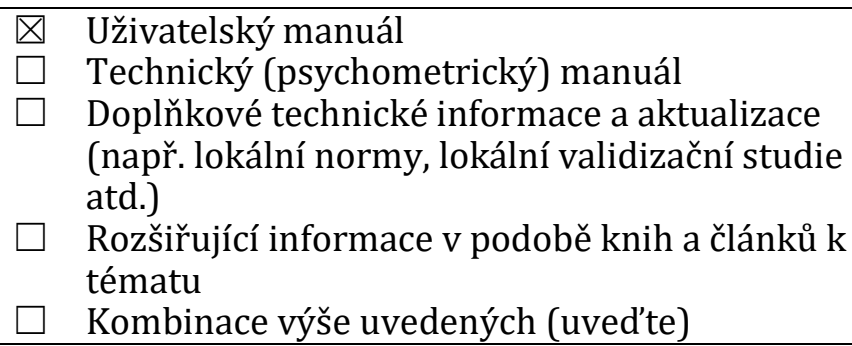 \\
\hline 1.24 & Metody publikace & $\begin{array}{ll} & \text { Papír } \\
\square & \text { PC - Diskety } \\
\square & \text { PC - CD/ROM } \\
\square & \text { Download z internetu } \\
\square & \text { Živý internet (nástroj pracuje v internetovém } \\
\text { prohlížeči) } \\
\square \text { Jiné: }\end{array}$ \\
\hline
\end{tabular}




\begin{tabular}{|c|c|c|}
\hline 1.25 .1 & $\begin{array}{l}\text { Počáteční náklady. } \\
\text { Cena kompletní sady materiálů (všechny manuály a } \\
\text { další material nutný k aspoň jedné zkušební } \\
\text { administraci). Kolik uchazečú lze vyšetř̌ovat pomocí } \\
\text { materiálù získaných za počáteční náklady, kde tyto } \\
\text { náklady zahrnují materially pro opakované vyšetření. }\end{array}$ & $\begin{array}{l}\text { Celková cena pracovního kompletu je } 1937 \text { Kč bez } \\
\text { DPH. Pracovní komplet obsahuje } 1 \text { př́ručku, } 10 \\
\text { testových sešitů, } 100 \text { záznamových archů a } 2 \\
\text { vyhodnocovací šablony. } \\
\text { Cena za SIPO software je } 3890 \text { Kč bez DPH. } \\
\text { (Ceny jsou uváděny k prosinci 2020) }\end{array}$ \\
\hline 1.25 .2 & Opakující se náklady: & $\begin{array}{l}\text { Jedna sada obsahuje dalších } 100 \text { záznamových } \\
\text { archů a stojí } 356 \text { Kč bez DPH (prosinec 2020). }\end{array}$ \\
\hline 1.26 .1 & $\begin{array}{l}\text { Ceny za zprávy generované } \\
\text { softwarem nainstalovaným } \\
\text { uživatelem: }\end{array}$ & - \\
\hline 1.26 .2 & $\begin{array}{l}\text { Ceny za vyhotovení zprávy zaslené } \\
\text { prostřednictvím pošty/faxu: }\end{array}$ & - \\
\hline 1.26 .3 & $\begin{array}{l}\text { Ceny za vyhotovení zprávy zaslené } \\
\text { prostř̌ednictvím internetové služby: }\end{array}$ & - \\
\hline 1.27 & $\begin{array}{l}\text { Ceny za další služby a zpracování } \\
\text { dat: opravy nebo vývoj } \\
\text { automatických zpráv: }\end{array}$ & - \\
\hline 1.28 & $\begin{array}{l}\text { Kvalifikační požadavky na práci s } \\
\text { testem vyžadované dodavatelem } \\
\text { testu }\end{array}$ & $\begin{array}{l}\square \quad \text { Žádné } \\
\square \quad \text { Oprávnění (certifikát) pro specifický test } \\
\square \quad \text { Oprávnění (certifikát) pro obecné výkonové } \\
\text { testy: i. e. míry maximálního výkonu ve } \\
\text { schopnostech } \\
\square \text { Potvrzení v testování obecných schopností a } \\
\text { dovedností: míry maximálního výkonu ve } \\
\text { vztahu k potenciálu k výkonu } \\
\square \quad \begin{array}{l}\text { Potvrzení v obecné diagnostice a diagnostice } \\
\text { osobnosti: míry typického chování, postojů a } \\
\text { preferencí }\end{array} \\
\text { Jiné: } \\
\quad \text { Není uvedeno. }\end{array}$ \\
\hline 1.29 & 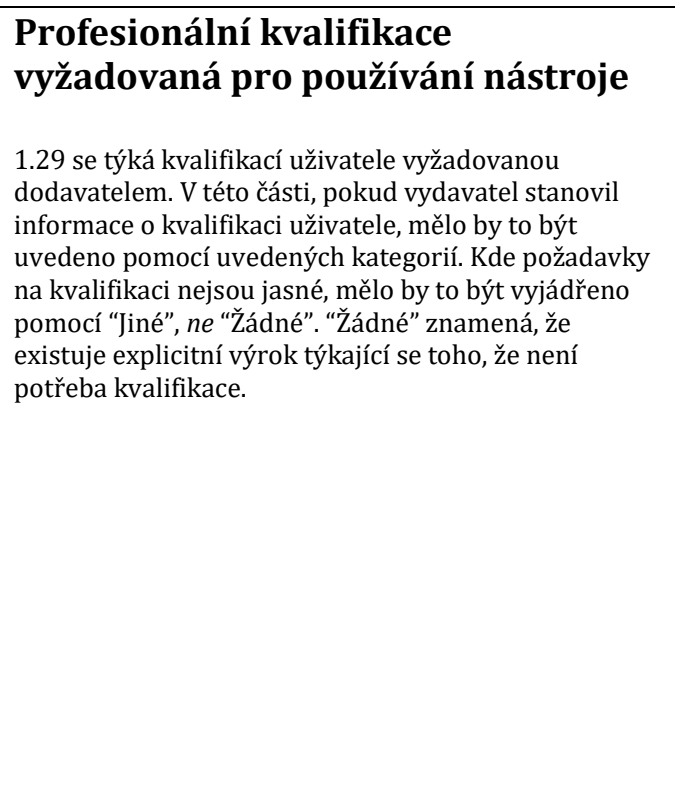 & 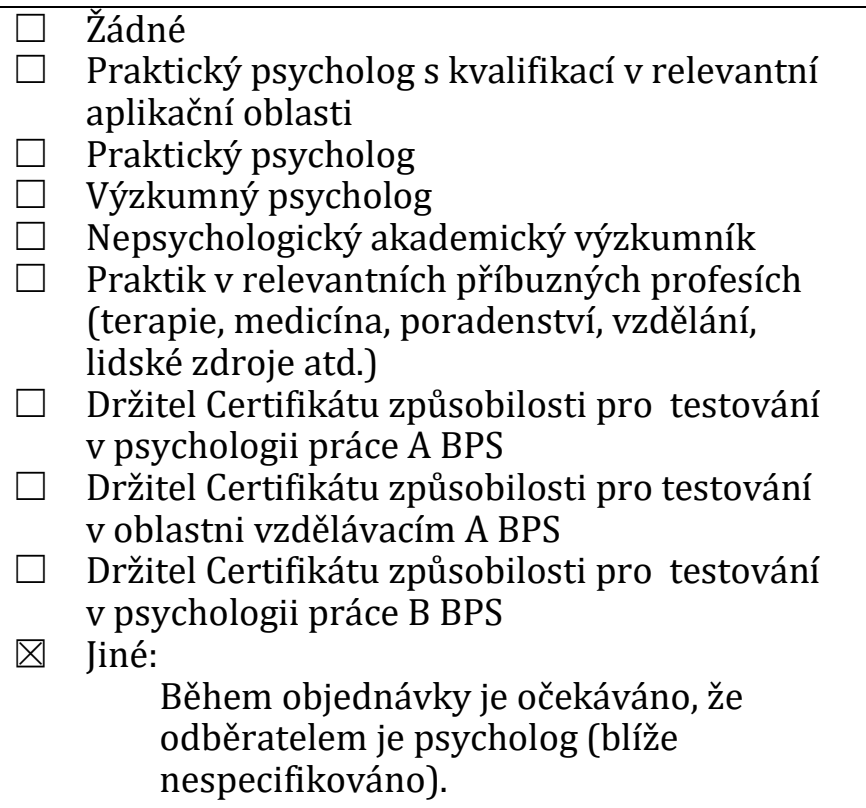 \\
\hline
\end{tabular}


Č́st 6:

Hodnocení testových materiálů

\section{Vysvětlení hodnocení}

V následujících částech jsou celková posouzení adekvátnosti informací týkajících se validity, reliability a norem zobrazeny automaticky tučně.

Jakýkoli nástroj s jedním nebo více posouzeními 0 nebo 2 týkajícími se atributů považovaných za kritické pro bezpečné používání nástroje, by neměl být považován za nástroj, který splňuje minimální standardy.

\begin{tabular}{|c|c|c|c|}
\hline $\begin{array}{l}\text { Vstup na posuzovacím } \\
\text { formuláři }\end{array}$ & $\begin{array}{l}\text { Posouzení podle } \\
\text { standardů EFPA }\end{array}$ & $\begin{array}{c}\text { Reprezentace recenze } v \\
\mathrm{UK}\end{array}$ & Vysvětlení \\
\hline [n/a] & {$[\mathrm{n} / \mathrm{a}]$} & [n/a ] & $\begin{array}{l}\text { Tento atribut není u tohoto } \\
\text { nástroje použitelný }\end{array}$ \\
\hline $\mathbf{0}$ & {$[-]$} & [None ] & $\begin{array}{c}\text { Není možné posoudit jako } \\
\text { ne nebo nedostatek } \\
\text { poskytnutých informací }\end{array}$ \\
\hline 1 & {$[-1]$} & {$\left[\begin{array}{ll}* & ]\end{array}\right.$} & Neadekvátní \\
\hline 2 & & {$\left[\begin{array}{ll}* * & ]\end{array}\right.$} & NYNÍ NEPOUŽÍVÁNO \\
\hline 3 & {$\left[\begin{array}{ll}0 & ]\end{array}\right.$} & {$[* * *]$} & Adekvátní nebo přiměřený \\
\hline 4 & [ 1 ] & {$[* * * *]$} & Dobrý \\
\hline \multirow[t]{2}{*}{5} & [ 2 ] & {$[* * * * *]$} & Vynikající \\
\hline & & $\begin{array}{l}\text { [N.r.i.o.r] }{ }^{*} \text { (pouze pro } \\
\text { aktualizace) }\end{array}$ & $\begin{array}{l}\text { Položka nebyla v původní } \\
\text { recenzi posuzována }\end{array}$ \\
\hline
\end{tabular}

V této části má být provedeno více hodnocení různých aspektů nebo atributů dokumentace dodávané s nástrojem (nebo balíkem). Termín „dokumentace“ byl vybrán, aby pokrýval všechny ty materiály dodávané s nástrojem nebo snadno dostupné kvalifikovanému uživateli: např. manual administrátora; technické př́ručky; brožury s normami; dodatky k manuálu; aktualizace od vydavatelů/dodavatelů atd.

Položky mají být posuzovány n/a nebo 0 až 5 (poloviční rating je přijatelný)

Rating

\begin{tabular}{|c|c|c|}
\hline \multicolumn{2}{|c|}{$\begin{array}{l}\text { Kvalita vysvětlení principů, prezentace a kvalita poskytnuté informace: } \\
\text { (Tento celkový rating se získá použitím posouzení založeného na ratinzích daných pro položky 2.1-2.8) }\end{array}$} & 1 \\
\hline 2.1 & $\begin{array}{l}\text { Celkový rating kvality vysvětlení principů: (Tento celkový rating se získá použitím } \\
\text { posouzení založeného na hodnotách ratingů daných pro položky 2.1.1 - 2.1.5) }\end{array}$ & 1 \\
\hline 2.1.1 & i) Teoretické základy konstruktů: & 1 \\
\hline 2.1.2 & ii) Procedura vývoje testu: & 0 \\
\hline 2.1.3 & iii) Důkladnost analýz položek a model analýzy položek: & 0 \\
\hline 2.1.4 & iv) Vysvětlení obsahové validity: & 1 \\
\hline 2.1.5 & v) Souhrn relevantního výzkumu: & 0 \\
\hline
\end{tabular}




\begin{tabular}{|c|c|c|}
\hline 2.2 & $\begin{array}{l}\text { Adekvátnost dokumentace dostupné uživateli (uživatelské a technické } \\
\text { manuály, dodatky týkající se norem atd.): (Tento celkový rating se získá použitím } \\
\text { posouzení založeného na hodnotách ratingů daných pro položky } 2.2 .1-2.2 .6 \text { ) } \\
\text { Pro část } 2.2 \text { jsou stanoveny následující „měřítka“ pro rating „vynikající“ (5). Pozornost je zde zaměřena } \\
\text { na kvalitu pokrytí poskytnutého v dokumentaci dostupné kvalifikovaným uživatelům. Všimněte si, že část } \\
2.2 \text { se týká úplnosti a jasnosti dokumentace dostupné uživateli (uživatelské a technické manually, doadtky } \\
\text { k normám atd.) v pojmech pokrytí a vysvětlení. V pojmech kvality nástroje, jak ji dosvědčuje dokumentace, } \\
\text { jsou rozpracovány oblasti v této části pod čísly: } 2.1,2.3,2.9,2.10 \text { a } 2.11 \text {. }\end{array}$ & 1 \\
\hline 2.2 .1 & $\begin{array}{l}\text { Principy: [viz 2.1] } \\
\text { Dobře argumentovaný a jasně prezentovaný popis toho, co má podle návrhu měřit a proč byl zkonstruován } \\
\text { tak, jak je. }\end{array}$ & 1 \\
\hline 2.2 .2 & $\begin{array}{l}\text { Vývoj: } \\
\text { Úplné detaily týkající se zdrojů položek, pilotáže, analýz položek, srovnávacích studií a změn prováděných v } \\
\text { prưběhu vývojových pokusů. }\end{array}$ & 0 \\
\hline 2.2 .3 & $\begin{array}{l}\text { Standardizace: } \\
\text { Jasné a detailní informace poskytnuté o velikostech a zdrojích standardizačního souboru a standardizační } \\
\text { proceduře. }\end{array}$ & 0 \\
\hline 2.2 .4 & $\begin{array}{l}\text { Normy: } \\
\text { Jasné a detailní informace poskytnuté o velikostech a zdrojích normalizačních skupin, podmínkách vyšetření } \\
\text { atd. }\end{array}$ & 1 \\
\hline 2.2 .5 & $\begin{array}{l}\text { Reliabilita: } \\
\text { Dobré vysvětlení reliability a široký rozsah měr vnitřní konsistence a retestu spolu s vysvětlením jejich } \\
\text { relevance a zobecnitelnosti nástroje vyšetření. }\end{array}$ & 0 \\
\hline 2.2 .6 & $\begin{array}{l}\text { Validita: } \\
\text { Dobré vysvětlení validity spolu s širokou škálou studií jasně a poctivě popsaných. }\end{array}$ & 0 \\
\hline 2.3 & $\begin{array}{l}\text { Kvalita procedurálních instrukcí poskytnutých uživateli: (Tento celkový rating se } \\
\text { získá s použitím posouzení na základě hodnot ratingů daných pro položky } 2.3 .1-2.3 .7 \text { ) }\end{array}$ & 1 \\
\hline 2.3 .1 & $\begin{array}{l}\text { Pro administraci testu: } \\
\text { Poskytnutá jasná a detailní vysvětlení a procedurální průvodce krok za krokem spolu s dobrými radami } \\
\text { týkajícícmi se otázek uchazečú a problémových situací. }\end{array}$ & 3 \\
\hline 2.3 .2 & $\begin{array}{l}\text { Pro skórování testu, normy atd.: } \\
\text { Poskytnuté jasné a detailní informace spolu s popsanými kontrolami pro vyhnutí se možným chybám } \\
\text { skórování. }\end{array}$ & 3 \\
\hline 2.3 .3 & $\begin{array}{l}\text { Pro interpretaci a vytváření zpráv: } \\
\text { Detailní doporučení týkající se interpretace různých skórů, chápání normativních měr a zacházení se vztahy } \\
\text { mezi různými škálami, s množstvím ilustrativních příkladů a př́ípadových studií. }\end{array}$ & 1 \\
\hline 2.3 .4 & $\begin{array}{l}\text { Pro poskytnutí zpětné vazby a debriefingu respondentům testu a dalším: } \\
\text { Detailní doporučení, jak prezentovat zpětnou vazbu uchazečum. }\end{array}$ & 0 \\
\hline 2.3 .5 & $\begin{array}{l}\text { Pro poskytování dobrých praktických témat týkajících se poctivosti a } \\
\text { zkreslení: } \\
\text { Uvedení detailních informací o studiích sexuálního a etnického zkreslení s relevantními varováními týkajícími } \\
\text { se používánía zobecňování validit. }\end{array}$ & 0 \\
\hline 2.3 .6 & $\begin{array}{l}\text { Omezení používání: } \\
\text { Jasné popisy, kdo by měl a kdo by neměl být vyšetřován spolu s dobře vysvětlenými odůvodněními těchto } \\
\text { omezení (např. typy nezpůsobilostí, požadované úrovně gramotnosti atd.). }\end{array}$ & 0 \\
\hline 2.3 .7 & $\begin{array}{l}\text { Reference a podpůrné materiály: } \\
\text { Detailní odkazy na relevantní podpůrnou akademickou literature a křížové odkazy na další př́ibuzné } \\
\text { materially týkající se diagnostických nástrojủ. }\end{array}$ & 0 \\
\hline \multicolumn{2}{|r|}{$\begin{array}{l}\text { Kvalita materiálů: } \\
\text { (Tento celkový rating se získá použitím posouzení založeného na hodnotách ratingů pro položky } 2.4-2.8 \text { ) }\end{array}$} & 3 \\
\hline 2.4 & $\begin{array}{l}\text { VŠeobecná kvalita materiálů testu } \\
\text { (testové brožury, odpověd'ové archy, testové objekty, software atd.): }\end{array}$ & 3 \\
\hline 2.5 & Kvalita lokální adaptace testu (pokud byl test přeložen a adaptován do místního jazyka): & 0 \\
\hline 2.6 & Snadnost, s jakou může respondent testu porozumět úkolu: & 4 \\
\hline 2.7 & $\begin{array}{l}\text { Snadnost, s jakou mohou být respondentem testu tvořeny reakce nebo } \\
\text { odpovědi: }\end{array}$ & 4 \\
\hline 2.8 & Kvalita položek: & 1 \\
\hline
\end{tabular}


Manuál k testu postrádá mnoho základních informací. Autor v manuálu neposkytuje žádné odkazy na další relevantní výzkumy ani informace o vývoji metody. V manuálu není ani zmíněno, že je metoda původem převzata ze zahraničí. Celkově chybí bližší přiblížení teoretických východisek, ze kterých metoda vychází. Základním nedostatkem je také posouzení reliability a validity testu.

Pozitivní stránkou je snadná administrace testu. Zároveň vyhodnocení testu pomocí šablon je velmi jednoduché a převedení hrubého skóru na z-skór je dobře popsáno. Tam však pokyny končí a interpretace výsledků spolu se zpětnou vazbou testované osobě je závislá na odbornosti a úsudku uživatele testu.

Znepokojivým objevem je to, že minimálně jedna z položek testu sytí špatnou škálu. Položka 44a zní: „Respektovat názory druhých a řídit se jimi.“ Tato položka má podle vyhodnocovací šablony sytit škálu dominance, ale evidentně jde v rozporu s definicí dominance v manuálu testu. U žádných jiných položek nebyl nalezen problém. Je mrzuté, že během vývoje testu neproběhla faktorová analýza, která by mohla takové věci odhalit.

\section{Č́st 7:}

\section{Hodnocení norem, reliability a validity}

Rating

\section{Informace o normách nebo referenční skupině}

\begin{tabular}{|c|c|c|}
\hline 2.9 & Celková adekvátnost: & 1 \\
\hline 2.9 .1 & $\begin{array}{cl}\begin{array}{c}\text { Vhodnost pro lokální použití, at' už pro lokální nebo mezinárodní normy: } \\
{[\mathrm{n} / \mathrm{a}]}\end{array} & \begin{array}{c}\text { Nepoužitelné } \\
0\end{array} \\
\begin{array}{l}\text { Žádná informace nepodána. } \\
\text { Není lokálně relevantní (např. nevhodné zahraniční výběry). }\end{array} \\
\begin{array}{l}\text { Lokální výběr z obecné populace nebo nelokální normy, které lze } \\
\text { použít s varováním. }\end{array} \\
\begin{array}{l}\text { Výběry lokální země nebo relevantní mezinárodní výběry s dobrou } \\
\text { relevancí pro zamýšlenou aplikaci. }\end{array} \\
\begin{array}{l}\text { Výběry lokální země nebo relevantní mezinárodní výběry vybrané z } \\
\text { dobře definovaných výběrů z relevantních aplikačních oblastí. }\end{array}\end{array}$ & 0 \\
\hline 2.9 .2 & $\begin{array}{cl}\begin{array}{l}\text { Vhodnost pro zamýšlené aplikace: } \\
{[\mathrm{n} / \mathrm{a}]}\end{array} & \text { Nepoužitelné } \\
0 & \text { Žádná informace nepodána. } \\
1 & \text { Norma nebo normy nejsou adekvátní pro zamýšlené aplikace. } \\
3 & \text { Adekvátní normy pro obecnou populaci a/nebo rozmezí normativních } \\
& \text { tabulek. } \\
4 & \text { Dobré rozmezí normativních tabulek. } \\
5 & \begin{array}{l}\text { Vynikající rozmezí výběrově relevantních norem vztahujících se k věku } \\
\text { a pohlaví, s informacemi o dalších rozdílech v rámci skupin (např. } \\
\end{array} \\
& \text { směs etnických skupin). } \\
\end{array}$ & 0 \\
\hline 2.9 .3 & $\begin{array}{cl}\begin{array}{l}\text { Velikosti výběrů: } \\
{[\mathrm{n} / \mathrm{a}]}\end{array} & \text { Nepoužitelné } \\
0 & \text { Žádná informace nepodána. } \\
1 & \text { Neadekvátní výběry (např. méně než 150). } \\
3 & \text { Adekvátní výběry (např. 150-300). } \\
4 & \text { Velké výběry (např. 300-1000). } \\
5 & \text { Velmi velké výběry (např. 1000+). }\end{array}$ & 5 \\
\hline
\end{tabular}




\begin{tabular}{|c|c|c|c|}
\hline 2.9 .4 & $\begin{array}{c}\text { Procedu } \\
\text { (vyberte je } \\
\square \\
\square \\
\square \\
\square\end{array}$ & $\begin{array}{l}\text { ité při výběru souboru: } \\
\text { dnot'te kvalitu použitého postupu) } \\
\text { Žádná informace neposkytnuta } \\
\text { Reprezentativní populaci [sumarizujte kritéria] } \\
\text { Nahodilá } \\
\text { Náhodná }\end{array}$ & 0 \\
\hline 2.9 .5 & $\begin{array}{l}\text { Kvalita i } \\
\text { vlivech } \\
\qquad \mathrm{n} / \mathrm{a} \\
0 \\
1 \\
3 \\
4 \\
5\end{array}$ & $\begin{array}{l}\text { cí poskytnutých o minoritní/chráněné skupině, rozdílech, } \\
\text { du atd.: } \\
\text { Nepoužitelné } \\
\text { Žádná informace nepodána. } \\
\text { Neadekvátní informace. } \\
\text { Adekvátní obecné informace s minimální analýzou. } \\
\text { Dobré popisy a analýzy skupin a rozdílů } \\
\text { Vynikající série analýz a diskuse o relevantních tématech vztahujících } \\
\text { se k použití a interpretaci. }\end{array}$ & 1 \\
\hline
\end{tabular}

2.9.6 Komentáře recenzentů k normám: Stručná zpráva o normách a jejich historii, včetně informací o doporučeních učiněných vydavatelem/autorem pro aktualizaci norem obvyklým způsobem.

V původní metodě použil autor pro konstrukci norem 5 vzorků americké populace napříč věkem a vzděláním dohromady čítající 13856 respondentů. Menšinové skupiny byly zastoupeny napříč těmito vzorky, což je dle autora důkazem reprezentativnosti amerického vzorku (Gordon, cit. podle Kaczmarek \& Packer, 1997). Hrubé skóry se v dotazníku SIV převádí na percentily.

Autor české metody zjistil na vzorku 752 mužů od 18 do 56 let, že jednotlivé škály jsou nezávislé na věku, tudíž v ručním vyhodnocování se s věkovými normami nepracuje. Ačkoliv byla věková nezávislost zkoumána pouze u lidí starších 18 let, vydavatel testu uvádí, že metoda je vhodná pro respondenty od 13 let. Při ručním vyhodnocení pracuje člověk bud' s normami pro muže $(n=5090)$, nebo pro ženy $(n=2730)$. Velikost obou skupin je velmi uspokojivá a toto rozhodně oceňuji. V příručce však nejsou uvedeny žádné informace o tom, jakým způsobem byl tento soubor sesbírán, ani žádné další charakteristiky zkoumaného vzorku (včetně vzdělání, věku nebo stáří norem). Uživatel testu nemá mnoho informací, aby posoudil, s jakou populací je skóre respondenta porovnáváno.

\section{Validita}

\begin{tabular}{|c|c|c|}
\hline 2.10 & $\begin{array}{l}\text { Celková adekvátnost: (Tento celkový rating se získá na základě posouzení hodnot ratingů } \\
\text { daných v položkách } 2.10 .1-2.10 .2 .4 \text {. Neprůměrujte pouze čísla, abyste získali celkový rating. } \\
\text { Obvykle bude roven bud' konstruktové validitě nebo validitě vztahující se ke kritériu, podle } \\
\text { toho, která z nich je vyšší.) }\end{array}$ & $\mathbf{0}$ \\
\hline 2.10 .1 & $\begin{array}{l}\text { Konstruktová validita - celková adekvátnost } \\
\text { (Tento celkový rating se získá na základě posouzení hodnot ratingů daných v položkách } \\
2.10 .1 .2-2.10 .1 .6 \text {. Neprüměrujte pouze čísla, abyste tento celkový rating získali.) }\end{array}$ & $\mathbf{0}$ \\
\hline 2.10 .1 .1 & $\begin{array}{cl}\text { Použité plány: (zatrhněte tolik, kolikje jich použitelných) } \\
\square \quad \text { Žádná informace nepodána } \\
\square \quad \text { Korelace s dalšími nástroji a výkonovými kritérii } \\
\square \quad \text { Vnitroškálový (korelace položky se zbytkem) } \\
\square \quad \text { Rozdíly mezi skupinami } \\
\square \quad \text { Matice mnoha rysů a mnoha metod (MTMM) } \\
\square \quad \text { Explorační faktorová analýza } \\
\square \quad \text { Konfirmační faktorová analýza } \\
\square \quad \text { Experimentální plány } \\
\square \quad \text { Jiné: uved'te }\end{array}$ & \\
\hline
\end{tabular}




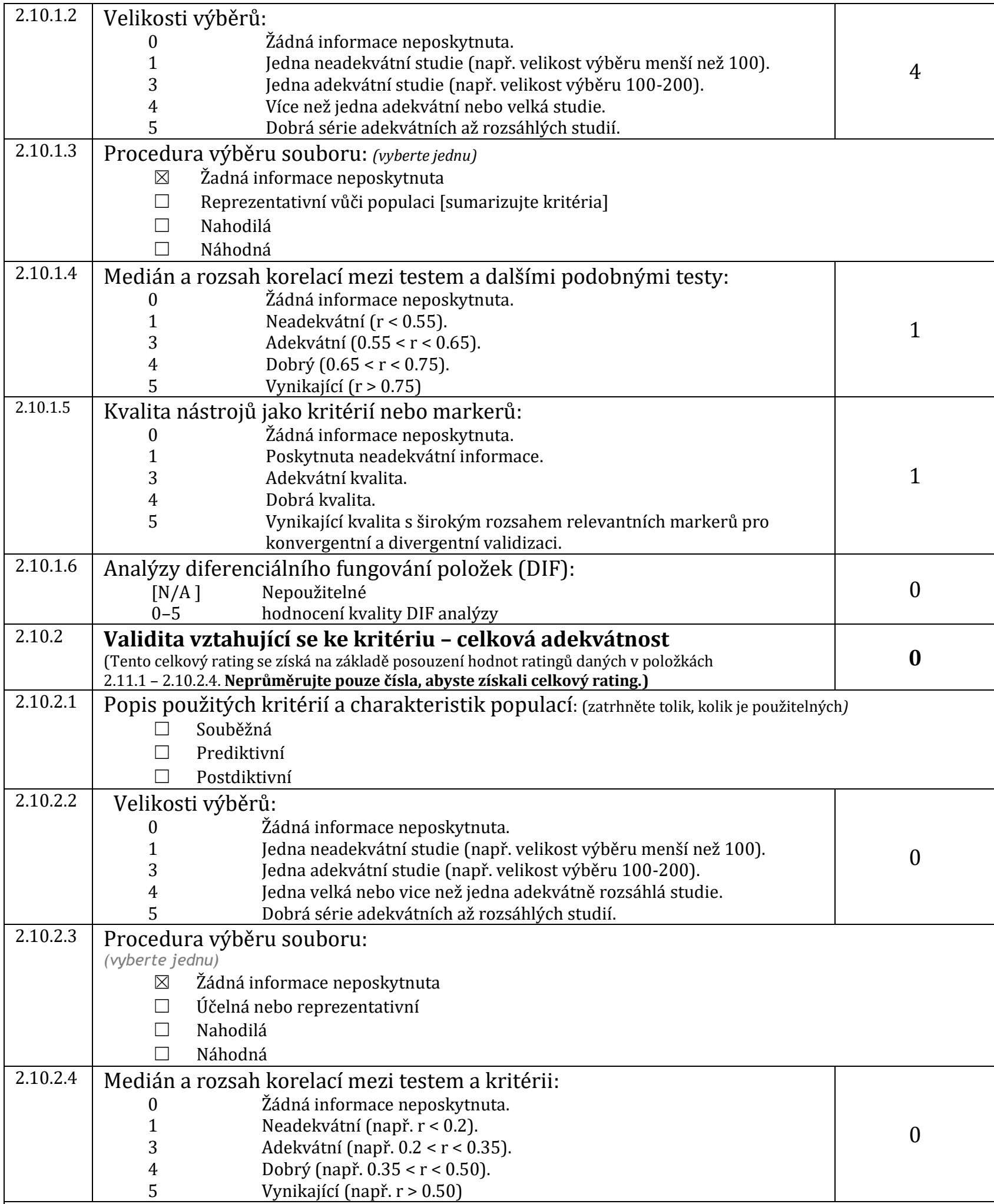

\subsubsection{Komentáře recenzenta týkající se validity:}

Autor české metody se $\mathrm{k}$ validitě nikde $\mathrm{v}$ manuálu explicitně nevyjadřuje. Mikšík se $\mathrm{v}$ psychometrické části příručky věnuje především korelacím mezi dotazníkem SIPO a dalšími nástroji (převážně se zaměřuje na korelace s dalšími Mikšíkovými testy). Většina těchto výsledků je pro posouzení kvality metody nepodstatná a autor nevysvětluje z jakého důvodu jim věnuje takový prostor. Nicméně se dá z některých výsledků alespoň zčásti usuzovat na konstruktovou validitu. Korelační analýza dotazníku SPARO s dotazníkem SIPO byla provedena na vzorku 4732 mužů a 2531 žen. Výsledky ukazují: korelaci mezi konformitou 
(SPARO) a projevováním konformity (SIPO) $r=0,39$ pro muže a $r=0,41$ pro ženy; korelaci mezi hladinou benevolence a tolerance (SPARO) a altruismem (SIPO) $r=0,20$ pro muže a $r=$ 0,23 pro ženy; korelaci mezi tendencí k nezávislosti (SPARO) a očekáváním nezávislosti (SIPO) $r=0,37$ pro muže a $r=0,36$ pro ženy. Autor také zkoumal na 307 mužích vztah dotazníku SIPO s dotazníkem interpersonální orientace FIRO-B. Zde se dá pro účely konstruktové validity zaměřit na: korelaci mezi mírou kontrolování druhých (FIRO-B) a projevováním dominance (SIPO) $\mathrm{r}=0,42$; korelaci mezi potřebou být milován (FIRO-B) a očekáváním uznání (SIPO) $\mathrm{r}=-$ 0,10. Mikšík nikde nereflektuje to, že některé tyto hodnoty jsou neuspokojivě nízké.

Původní verze metody vykazuje dobrou úroveň prediktivní, faktorové i konstruktové validity (Kaczmarek \& Packer, 1997). Dobrá validita původní metody však nemusí znamenat dobrou validitu české metody.

\section{Reliabilita}

\begin{tabular}{|c|c|c|c|}
\hline 2.11 & $\begin{array}{l}\text { Celková adekvá } \\
\text { (Tento celkový rating se } \\
\text { Neprüměrujte pouze c }\end{array}$ & $\begin{array}{l}\text { Ǵtnost: } \\
\text { e získá na základě posouzení hodnot ratingů daných v položkách 2.11.1-2.10.2.4. } \\
\text { ćisla, abyste získali celkový rating.) }\end{array}$ & $\mathbf{0}$ \\
\hline 2.11 .1$. & $\begin{array}{r}\text { Poskytnutá data } \\
\quad \square \quad \text { Uveden } \\
\square \quad \text { Uveden } 1 \\
\square \quad \text { Koeficie } \\
\square \quad \text { Standarc }\end{array}$ & $\begin{array}{l}\text { týkající se reliability: (vyberte jednu možnost) } \\
\text { pouze jeden koeficient reliability } \\
\text { pouze jeden odhad standardní chyby měření } \\
\text { nty reliability pro několik různých skupin } \\
\text { dní chyba měření uvedená pro několik různých skupin }\end{array}$ & \\
\hline 2.11 .1 & Vnitřní konzisten & רce: & \\
\hline 2.11 .1 .1 & $\begin{array}{l}\text { Velikost výběru: } \\
0 \\
1 \\
3 \\
4 \\
5 \\
{[\mathrm{~N} / \mathrm{A}]}\end{array}$ & $\begin{array}{l}\text { Neposkytnuta žádná informace. } \\
\text { Jedna neadekvátní studie (např. rozsah výběru menší než 100). } \\
\text { Jedna adekvátní studie (např. rozsah výběru 100-200). } \\
\text { Jedna rozsáhlá nebo vice než jedna adekvátně rozsáhlá studie. } \\
\text { Dobrá série adekvátních až rozsáhlých studií. } \\
\text { Nepoužitelné. }\end{array}$ & 0 \\
\hline 2.11.1.2 & $\begin{array}{l}\text { Medián koeficien } \\
0 \\
1 \\
3 \\
4 \\
5 \\
{[\mathrm{~N} / \mathrm{A}]}\end{array}$ & $\begin{array}{l}\text { ntů: } \\
\text { Neposkytnuta žádná informace. } \\
\text { Neadekvátní (např. } r<0.7 \text { ) } \\
\text { Adekvátní (např. } r=0.7 \text { až } 0.79 \text { ) } \\
\text { Dobrý (např. } r=0.8 \text { až } 0.89 \text { ) } \\
\text { Vynikající (např. r }>0.9 \text { ) } \\
\text { Nepoužitelné. }\end{array}$ & 0 \\
\hline 2.11 .2 & \multicolumn{3}{|c|}{ Testová-retestová stabilita: } \\
\hline 2.11 .2 .1 & $\begin{array}{l}\text { Rozsah výběru: } \\
0 \\
1 \\
3 \\
4 \\
5 \\
\end{array}$ & $\begin{array}{l}\text { Neposkytnuta žádná informace. } \\
\text { Jedna neadekvátní studie (např. rozsah výběru menší než 100). } \\
\text { Jedna adekvátní studie (např. rozsah výběru 100-200). } \\
\text { Jedna rozsáhlá nebo vice než jedna adekvátně rozsáhlá studie. } \\
\text { Dobrá série adekvátních až rozsáhlých studií. }\end{array}$ & 0 \\
\hline 2.11 .2 .2 & $\begin{array}{l}\text { Medián koeficien } \\
0 \\
1 \\
3 \\
4 \\
5\end{array}$ & $\begin{array}{l}\text { Nů: } \\
\text { Neposkytnuta žádná informace. } \\
\text { Neadekvátní (např. } r<0.6 \text { ) } \\
\text { Adekvátní (např. } r=0.6 \text { až } 0.69 \text { ) } \\
\text { Dobrý (např. } r=0.7 \text { až } 0.79 \text { ) } \\
\text { Vynikající (např. } r>0.8 \text { ) }\end{array}$ & 0 \\
\hline 2.11 .3 & Reliabilita jako & kvivalence: & \\
\hline
\end{tabular}




\begin{tabular}{|c|c|c|c|}
\hline 2.11.3.1 & $\begin{array}{l}\text { Rozsah výběru: } \\
0 \\
1 \\
3 \\
4 \\
5 \\
{[\mathrm{~N} / \mathrm{A}]} \\
\end{array}$ & $\begin{array}{l}\text { Neposkytnuta žádná informace. } \\
\text { Jedna neadekvátní studie (např. rozsah výběru menší než 100). } \\
\text { Jedna adekvátní studie (např. rozsah výběru 100-200). } \\
\text { Jedna rozsáhlá nebo vice než jedna adekvátně rozsáhlá studie. } \\
\text { Dobrá série adekvátních až rozsáhlých studií. } \\
\text { Nepoužitelné. }\end{array}$ & 0 \\
\hline 2.11 .3 .2 & $\begin{array}{c}\text { Medián koeficie } \\
0 \\
1 \\
3 \\
4 \\
5 \\
{[\mathrm{~N} / \mathrm{A}]}\end{array}$ & $\begin{array}{l}\text { ntů: } \\
\text { Neposkytnuta žádná informace. } \\
\text { Neadekvátní (např. } r<0.6 \text { ) } \\
\text { Adekvátní (např. r }=0.6 \text { až 0.69) } \\
\text { Dobrý (napřr. r }=0.7 \text { až } 0.79 \text { ) } \\
\text { Vynikající (např. r>0.8) } \\
\text { Nepoužitelné }\end{array}$ & 0 \\
\hline
\end{tabular}

\subsubsection{Komentáře recenzentů k reliabilitě:}

- Komentujte intervaly spolehlivosti pro koeficienty reliability

- Uved'te Spearmanovy-Brownovy ekvivalenty

Autor původní metody ověřoval test-retest reliabilitu na několika vzorcích. Vysokoškolští studenti $(n=79)$ byli znovu otestováni po desíti dnech a jejich koeficienty byly mezi $\mathrm{r}=0,78$ až $\mathrm{r}=0,89$. Koeficienty reliability pro dobrovolníky z mírových sborů $(\mathrm{n}=58)$ retestovaných po 12 týdnech byly mezi $r=0,55$ až $r=0,79$. Koeficienty pro další retestované vzorky ukazovaly podobné hodnoty. Vnitřní konzistence škál se pro vysokoškolské studenty $(\mathrm{n}=186)$ pohybovala mezi KR20 = 0,71 až KR20 = 0,86. Podobně pro studenty střední školy ( $n=144$ ) byla vnitřní konzistence pro jednotlivé škály mezi KR20 =0,75 až KR20 = 0,86 (Gordon, cit. podle Kaczmarek \& Packer, 1997). Koeficienty původní metody ukazují většinou dostatečně dobrou úroveň reliability.

Víceméně uspokojivá reliabilita originální verze však neznamená podobnou reliabilitu české verze, zvláště protože originální metoda používá jinou strukturu položek v dotazníku. Autor české metody vůbec koeficienty reliability neuvádí. Rovněž manuál neposkytuje žádné informace $\mathrm{k}$ intervalům spolehlivosti a standardní chybě měření.

\section{Část 9:}

\section{Závěrečné hodnocení:}

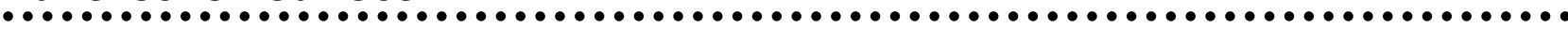

3.0 Hodnotící zpráva testu:

Tato část by měla obsahovat stručné, jasně obhájené posouzení nástroje/produktu. Mělo by popisovat jeho pro a proti a poskytnout určitá obecná doporučení týkající se toho, jak a kdy by se měl používat - spolu s varováními (kde jsou potřebná) týkajícími se př́ípadů, kde by se používat neměl.

Dotazník SIPO má dle mého názoru několik problémových částí, které nemusí být při koupi testu zřejmé. Manuál $\mathrm{k}$ testu postrádá mnoho základních informací. Autor v manuálu neposkytuje žádné údaje o vývoji metody ani to, že metoda je adaptací už existující zahraniční metody. Zároveň zde autor neposkytuje žádné odkazy na další relevantní výzkumy. Nenávazností na širší psychologické poznání a specifičností použitého jazyka působí metoda velmi vytrženým dojmem, jako by autor vycházel $z$ nějaké úplně jiné psychologie. Celkově chybí bližší přiblížení teoretických východisek, ze kterých metoda vychází. V manuálu také chybí postup tvorby položek a položková analýza. Tento nedostatek se odráží na kvalitě položek, z nichž některé se zdají být problematické už jen při jejich pročtení.

Základním nedostatkem je také propracovaný psychometrický manuál, který by se blíže zabýval reliabilitou, validitou a normami. V psychometrické části manuálu se autor převážně 
věnuje korelacím mezi nástrojem SIPO a dalšími nástroji. Většina těchto výsledků je však poměrně nepodstatná k posouzení kvality metody. Výběr metod a přehledy korelací působí nejasným dojmem, protože autor neuvádí, za jakým účelem jsou tyto výsledky prezentovány.

Dotazník interpersonálních hodnot SIPO je snadným nástrojem, jehož administrace je velmi krátká a vyhodnocování pomocí šablon je jednoduché. Na druhou stranu manuál k dotazníku SIPO neposkytuje skoro žádné údaje ke kvalitnímu zhodnocení jeho psychometrických vlastností. Hlavním nedostatkem jsou chybějící důkazy validity a reliability. Dalším problémem jsou také nedostatečné informace k používaným normám, které mohou být pro účel testování neadekvátní nebo zastaralé.

\subsection{Závěry:}

Dotazník SIPO postrádá základní psychometrické důkazy. Bez těchto důkazů se nedá posoudit kvalita metody. Z těchto důvodů nelze doporučit dotazník SIPO k praktickému používání.

\begin{tabular}{|c|c|}
\hline \multicolumn{2}{|c|}{ 4.0 Doporučení (vyberte jedno) } \\
\hline \multicolumn{2}{|c|}{$\begin{array}{l}\text { Všechny následující charakteristiky } \\
\text { uvedené níže by měly mít ratingy } \\
\text { [n/a], [2], [4], [5], pokud by měl být } \\
\text { nástroj „doporučen“ pro obecné } \\
\text { použití (hodnocení } 5 \text { nebo 6): }\end{array}$} \\
\hline [2.9] & Normy a referenční skupiny \\
\hline$[2.10 .1]$ & Konstr \\
\hline$[2.10 .2]$ & Kriteriální validita \\
\hline [2.11] & Reliabilita - celková \\
\hline $\begin{array}{l}{[2.12]} \\
\text { zprávy }\end{array}$ & Počítačově generované \\
\hline $\begin{array}{l}\text { Pokud má } \\
\text { ratingů ho } \\
\text { měl být k } \\
1,2,3 \text { neb } \\
\text { doporuče }\end{array}$ & $\begin{array}{l}\text { terýkoli z výše uvedených } \\
\text { notu [] nebo [1], nástroj by } \\
\text { ifikován pod doporučením } \\
\text { 4, nebo klasifikován pod } \\
\text { m } 7 \text { “jiné” s adekvátním } \\
\text {. }\end{array}$ \\
\hline
\end{tabular}

\} 1 \text { Pouze výzkumný nástroj. Ne pro užití v praxi. }

2 Vhodný pouze pro užití expertním uživatelem za pečlivě kontrolovaných podmínek nebo ve velmi omezených aplikačních oblastech

3 Vhodný pro použití pod supervizí $\mathrm{v}$ aplikační(ch) oblasti(ech) definovaných distributorem, libovolnými uživateli s obecnými kompetencemi pro používání a administraci testů

4 Vyžaduje další vývoj. Vhodný pouze pro použití ve výzkumu.

5 Vhodný pro používání $\mathrm{v}$ aplikační(ch) oblasti(ech) definovaných distributorem, uživateli testů, kteří splňují speciální kvalifikační požadavky distributora

6 Vhodný pro sebevyšetření bez supervise v aplikační(ch) oblasti(ech) definovaných distributorem

7 Jiné:

\section{Odkazy k poznámkám a bibliografie}

Kaczmarek, A. \& Packer, J. (1997). Determination of a job-related test battery for the psychological screening of police applicants. Payneham: National Police Research Unit. Mikšík, O. (1999). Psychologické teorie osobnosti. Praha: Karolinum.

Mikšík, O. (2001). Psychologická charakteristika osobnosti. Praha: Karolinum.

Svoboda, M., Humpolíček, P., \& Šnorek, V. (2013). Psychodiagnostika dospělých. Portál. 
1. Očekávání porozumění

2. Očekávání uznání

3. Očekávání nezávislosti

4. Projevování dominance

5. Projevování konformity

6. Projevování altruismu 